\title{
Analysis of the Silting Rate in the "Hachef" Dam Situated in Northern Morocco in the Context of Global Change
}

\author{
Abderrahim El Boukhari', Mohamed Chikhaoui' ${ }^{2}$, Hicham Mharzi-Alaoui ${ }^{3}$, Mustapha Naimi' ${ }^{2}$ \\ ${ }^{1}$ Center for Doctoral Studies, IAV Hassan II, Rabat, Morocco \\ ${ }^{2}$ Department of Natural Resources \& Environment, IAV Hassan II, Rabat, Morocco \\ ${ }^{3}$ National Center for Climatic and Forest Risk Management, Rabat, Morocco \\ Email: abderrahimelboukhari@gmail.com
}

How to cite this paper: El Boukhari, A., Chikhaoui, M., Mharzi-Alaoui, H. and Naimi, M. (2020) Analysis of the Silting Rate in the "Hachef" Dam Situated in Northern Morocco in the Context of Global Change. Journal of Geographic Information System, 12, 112-124. https://doi.org/10.4236/jgis.2020.122007

Received: March 10, 2020

Accepted: April 18, 2020

Published: April 21, 2020

Copyright (C) 2020 by author(s) and Scientific Research Publishing Inc. This work is licensed under the Creative Commons Attribution International License (CC BY 4.0).

http://creativecommons.org/licenses/by/4.0/

\section{(c) (i) Open Access}

\begin{abstract}
The Moroccan annual dam silting corresponds to a loss in storage capacity of the reservoirs of about 75 million $\mathrm{m}^{3}$ per year. Land use metamorphosis and the ongoing climate changes are likely to accelerate the process of soil degradation and erosion. In this delicate context, Morocco will have to provide appropriate responses in terms of adaptation and remediation strategies to the degradation of soil and water resources. The objectives of this paper are to characterize the Specific Degradation (SD) of the Tangier basin through the study of the silting of the watershed located upstream the Hachef dam and to analyze the silting rate of the Hachef dam according to the variability of precipitations and the dynamics of the vegetation convent. The adopted approach is based on the analysis of the bathymetric surveys of the Hachef Dam to characterize the SD and the analysis of the silting rate based on the characterization of the spatial and temporal variability of the two key factors of water erosion. The results of processing the bathymetric surveys over a 19-year analysis period (1995-2014) show an annual average total silting of about $11.46 \mathrm{Mm}^{3}$ and a corresponding SD of about $36.7 \mathrm{t} \cdot \mathrm{ha}^{-1} \cdot \mathrm{yr}^{-1}$. This study shows the significant influence of the spatial and temporal variability of precipitation and vegetation cover on the silting dynamics of dams.
\end{abstract}

\section{Keywords}

Dam Silting, Spatial and Temporal Variability, Hachef Dam, Morocco 


\section{Introduction}

Morocco's water resources are naturally limited by the country's geographical location and its exposure to climatic hazards.

In a context of scarcity of water resources, and to support the country's development, Morocco has long been committed to the establishment of major water infrastructure. The proactive dam construction policy has resulted in the establishment of 140 large dams with a total storage capacity of about 17.6 billion $\mathrm{m}^{3}[1]$.

With a mobilizable hydraulic potential of about 22 Billion $\mathrm{m}^{3} / \mathrm{year}$ and a water availability of $700 \mathrm{~m}^{3}$ per capita, Morocco's water sector is currently facing several natural and anthropogenic constraints, including water erosion of soils and their strong degradation.

Erosion repercussions are perceived both upstream, at the level of soil degradation, the basis of all agricultural, pastoral or forest production, and downstream at the level of the mobilization of water resources, a vital element for the socio-economic development of the country.

In Morocco, a country sheltering a lot of dams, water erosion is considered the main cause of soil degradation with direct effects ("on site", upstream) on the capacity of the soil to ensure its basic functions such as agricultural production, and indirect effects ("off site") downstream, leading to rapid silting of dams, turbidity of potable water and transport of nutrients and pollutants adsorbed on suspended particles.

The annual dam silting corresponds to a loss in storage capacity of the reservoirs of about 75 million $\mathrm{m}^{3}$ per year, i.e. a $0.5 \%$ drop in dam capacity [2]. This silting leads to a regulated or guaranteed loss of volume for users.

Considering the cost of developing water resources through dams, which varies between 0.6 and 2 dirhams per $\mathrm{m}^{3}$, the cost of dams silting varies between 45 million dirhams and 150 million dirhams, i.e. an average of 97.5 million dirhams.

Water erosion results from the synergistic effects of natural conditions and human activities. According to studies by Vezena and Bonn (2006) [3] and Boudhar et al. (2007) [4], population pressure and the expansion of crops cultivation, combined with the amplifying effects of climate change, have exposed land to runoff and thus to soil degradation through water erosion. The latter is considered by Pandey et al. (2009) [5] as a spatio-temporal phenomenon that is growing in several countries of the world.

The projections of the different climate scenarios show that northern Morocco, like the rest of the world, will undergo changes in rainfall and temperature regimes, with a temperature increase of $2.3^{\circ} \mathrm{C}$ to $2.9^{\circ} \mathrm{C}$ and a $10 \%$ to $30 \%$ decrease in rainfall by 2050 [6]. Climate change is also expected to alter the seasonality of rainfall patterns, while increasing the frequency and intensity of extreme hydrometeorological events such as droughts and floods, depending on the season and region. Changes in land use will result from these climate changes, in 
addition to other constraints such as the strong demographic growth observed around the Mediterranean. There is therefore an urgent need to respond to these global changes by proposing adaptation/remediation strategies to the degradation of soil and water resources.

The objectives of this paper are 1) to characterize the Specific Degradation (SD) of the Tanger bassin through the study of the silting of the watershed located upstream of the Hachef dam and 2) to analyze the silting rate of the said dam according to the variability of precipitations and the dynamics of the vegetation convent.

\section{Materials and Methods}

\subsection{Study Area}

The Tangiers area is mainly made up of the Atlantic basins of the three rivers, the Oued Mhahar, the Oued Hachef and the Oued Ayacha and the Mediterranean basins from Tangiers to Sebta. Surface water inputs in the area amount to $655 \mathrm{Mm}^{3} /$ year with a strong interannual irregularity characterized by alternating dry and wet sequences [7].

The Tangiers basin is characterized by a ratio of about $750 \mathrm{~m}^{3} / \mathrm{year} /$ inhabitant below the water stress threshold. This situation will be more accentuated in the future, due to the economic development of the basin, which will drain a significant migratory flow.

The Hachef Dam (Named Dam April 9, 1947), one of the four Dams in the hydraulic basin of tangier (Table 1), is located in the Western Rif about $30 \mathrm{~km}$ south of the city of Tangier and $15 \mathrm{~km}$ east of the city of Asilah. It is a homogeneous fill type dam made of alluvium and riprap. The maximum foundation height is $52 \mathrm{~m}$.

Table 1. Presentation of the dams of the Tangiers basin.

\begin{tabular}{ccccc}
\hline Hydraulic basin & Dam & Wadi & Year & Function \\
\hline & April 9, 1947 & Hachef & 1995 & AEPI \\
Tbn Batouta & Mhahar & 1977 & I, AEPI \\
Kharroub & Kharroub & Under construction & AEPI \\
& Ayacha & Ayacha & In project & AEPI
\end{tabular}

AEPI: Drinking and Industrial Water Supply/I: Irrigation.

The dam controls a catchment area of $218 \mathrm{Km}^{2}$. The drained inflows to the dam are on average $75 \mathrm{Mm}^{3} /$ year. At the normal reservoir coast, the dam offers a large storage capacity of more than $300 \mathrm{Mm}^{3}$, the equivalent of four times the natural inflow.

The climate of the studied region is Mediterranean, with two distinct seasons, a hot and dry summer season between May and October and a second rainy and cool season from November to April.

From a geological point of view, the watershed of the Hachef Dam is part of 
the outer domain of the Rif chain. It is located in a so-called Tangier unit belonging to the intra-Rifaine zone. This unit is made up of flyshs, clays and clayey sandstones, which are essentially impermeable. As a result of these formations, the aquifer system in the basin is limited to a few localized aquifers with very low recharge.

Figure 1 illustrates the situation of the study area as well as the location of the dams in the Tangiers basin.

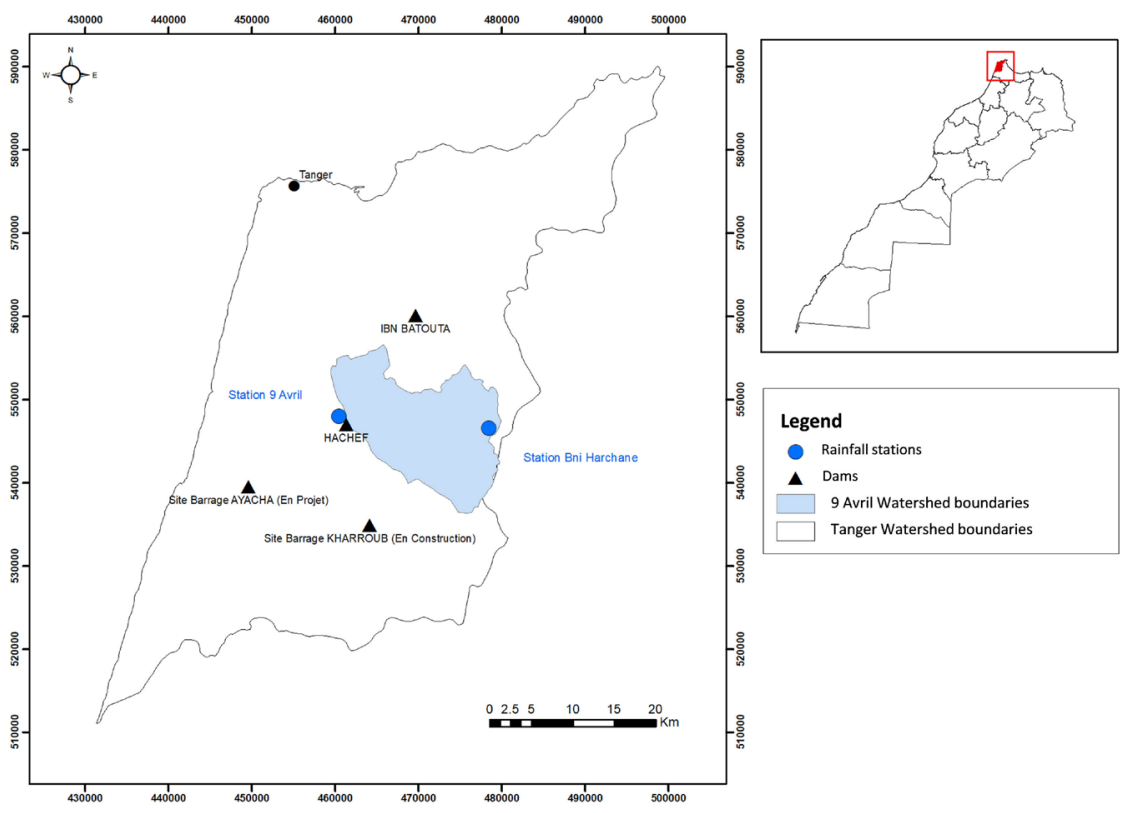

Figure 1. Geographic location of the study area.

\subsection{Sedimentation Study of the Dam Reservoirs}

Several methods are used to determine the silting rate of dam reservoirs; the bathymetric surveys [1] [8] [9] was chosen to the silting of the Hachef dam. This approach consists in the analysis of the bathymetric surveys established for the dam in order to quantify the silting rate and the determination of the corresponding Specific Degradation value. The calculus was done on the basis of a silt density equal to 1.3 , taking into account the rate of sediment trapped at reservoirs according to Brune's (1953) [10] calibration curve, which makes it possible to determine the trapping rate of a reservoir as a function of the ratio between the capacity of the dam and the average annual water inflow.

\subsection{Analysis of the Dynamic Factors of Water Erosion}

Rainfall erosivity and vegetation cover are considered key factors in modelling the soil loss equation. By characterizing the spatial and temporal variability of these two factors, it is possible to better assess the extent of soil degradation by the phenomenon of water erosion and to propose appropriate anti-erosion measures. For example, a rain shower can cause severe soil loss during summer fallow, but little damage during the growing season. Precipitation and vegetation 
cover are the factors that generally cause high intra-seasonal variability [11] [12] [13].

\subsubsection{Spatial and Temporal Rainfall Variability}

The rainfall erosivity factor $(\mathrm{R})$ is the parameter that evaluates the influence of climate aggressiveness on the soil surface [14].

The climatic aggressiveness index was calculated for a period of 20 years using the formula of Renard and Freimund which gives a result of the most appropriate erosivity (Lo and Guejjoud (2017)). It is also the most correlated with the results of Foster (2008) and Wishmeyer (1987) [2]. It's an annual formula and it's in the following form:

1) $\mathrm{R}=0.0483$ * $\mathrm{P}^{1.610}$, if $\mathrm{P}<850 \mathrm{~mm}$;

2) $\mathrm{R}=587.8-1.219 * \mathrm{P}+0.004105 * \mathrm{P}^{2}$, if $\mathrm{P}>850 \mathrm{~mm}$;

where $\mathrm{P}$ is the annual precipitation.

The rainfall data are from two rainfall stations located within the right-of-way of the Hachef Dam watershed (rainfall Station du 9 avril and Station Bni Harchane). They were provided by the Loukkos Watershed Agency (ABHL), associated with this study.

\subsubsection{Spatial and Temporal Monitoring of the Vegetation Cover}

There are various methods to study changes and evolution of vegetation cover through satellite images [14], one of which is the application of vegetation indices associated with green intensity. The NDVI (Normalized Difference Vegetation Index) is a measure of the balance between the energy received and the energy emitted by objects on Earth [15]. When applied to vegetation communities, various canopy characteristics can be estimated, including photosynthetic activity, cover rate, nature and structure of the canopy, surface water status, etc. It can thus be used to characterize the type of land use (forest, grassland, soil, water, etc.) available in a specific area.

The NDVI is a dimensionless index, so its value is between -1 and +1 . In practice, very low NDVI values $(<0.2)$ are indicative of water and bare soil, while higher values are indicative of vegetation.

Most of the studies that have attempted to assess NDVI on a large scale (watershed) have been conducted using Landsat images [14], which allow the use of different bands (visible, infrared, near infrared, etc.) at $30 \mathrm{~m}$ resolution.

The study was carried out on a series of Landsat 5, 7 and 8 images acquired during the period from September to December of the years 1995, 2000, 2009, 2014, provided free of charge by USGS (United States Geological Survey).

Radiometric and geometric corrections have already been performed on the images before their acquisition. They only had to be re-projected in the Lambert Conique Conforme projection system adopted in Morocco.

NDVI is constructed from the red (R) channel and the near infrared (PIR) channel. By highlighting the difference between the visible red band and the near infrared band according to the following formula: 
1) $\mathrm{NDVI}=(\mathrm{PIR}-\mathrm{R}) /(\mathrm{PIR}+\mathrm{R})$

where the PIR corresponds to the reflectance value of the near-infrared band and the $\mathrm{R}$ corresponds to that of the red band.

For Landsat TM and ETM+, the following formula was used:

2) $\mathrm{NDVI}=(\mathrm{B} 4-\mathrm{B} 3) /(\mathrm{B} 4+\mathrm{B} 3)$

where $\mathrm{B} 4$ is band 4 (0.76- 0.90 micrometer) corresponding to infrared and $\mathrm{B} 3$ is band 3 (0.63 - 0.69 micrometer) corresponding to red in Landsat TM and ETM+ images.

For Landsat 8 (OLI-TIRS), the following formula was used:

3) $\mathrm{NDVI}=(\mathrm{B} 5-\mathrm{B} 4) /(\mathrm{B} 5+\mathrm{B} 4)$

where $\mathrm{B} 5$ is band 5 corresponding to infrared with a wavelength ranging from 0.85 to 0.88 micrometer and B4 is band 4, with a wavelength between 0.64 and 0.67 micrometer, corresponding to red in Landsat 8 (OLI-TIRS) images.

The difference in wavelengths of the infrared and red bands between Landsat TM and ETM+ and Landsat 8 could impact the process of comparing NDVI values calculated in each satellite image. Indeed, according to the study by Peng Li \& al (2014), Landsat 8 OLI sensors, compared to those of ETM+, give higher values for the near-infrared band for vegetation cover, but a lower value for other types of land cover not covered by vegetation. On the other hand, Teillet and Ren (2008) justify the effect of the Spectral band difference effects (SBDE) on vegetation indices by the interaction between the responses of the spectral profiles of the sensors and by the spectral dependence of the atmospheric gas transmittance. Of particular importance is the effect of the difference in spectral bands (SBDE) of some vegetation indices calculated from red and infrared bands (NDVI) or green and blue bands (ARVI-Atmospherically Resistant Vegetation Index and MTVI-Modified Triangular Vegetation Index).

The inclusion of SBDE in the classification of satellite images for this study was also necessary to allow comparison between NDVI values for each land cover type. Thus the following values were used:

- $\quad$ Landsat TM and ETM +

\begin{tabular}{ccc}
\hline Code & Type of land use & NDVI values considered \\
\hline 1 & Water & $<0.1$ \\
2 & Bare soil & 0.15 \\
3 & Sparse vegetation & 0.25 \\
4 & Moderately dense vegetation & 0.4 \\
5 & Dense vegetation & $>0.4$ \\
\hline
\end{tabular}

- $\quad$ Landsat 8 OLI

\begin{tabular}{ccc}
\hline Code & Type of land use & NDVI values considered \\
\hline 1 & Water & $<0.08$ \\
2 & Bare soil & 0.2 \\
3 & Sparse vegetation & 0.4 \\
4 & Moderately dense vegetation & 0.55 \\
5 & Dense vegetation & $>0.55$ \\
\hline
\end{tabular}




\section{Results and Discussion}

\subsection{Silting Analysis of the Hachef Dam}

We used the bathymetric surveys to analyze the rate of the dam silting and to establish the associated SD for the watershed feeding the studied dam.

At the date of the last bathymetric survey (2014) and with reference to the commissioning situation of the Hachef Dam, the total silting is of the order of $11.46 \mathrm{Mm}^{3}$, i.e. an average silting rate of $0.6 \mathrm{Mm}^{3} /$ year.

The analysis of the four bathymetric surveys carried out (1995, 2000, 2009 and 2014) made it possible to quantify the silting of the dam over the period 1995-2014 (Figure 2).

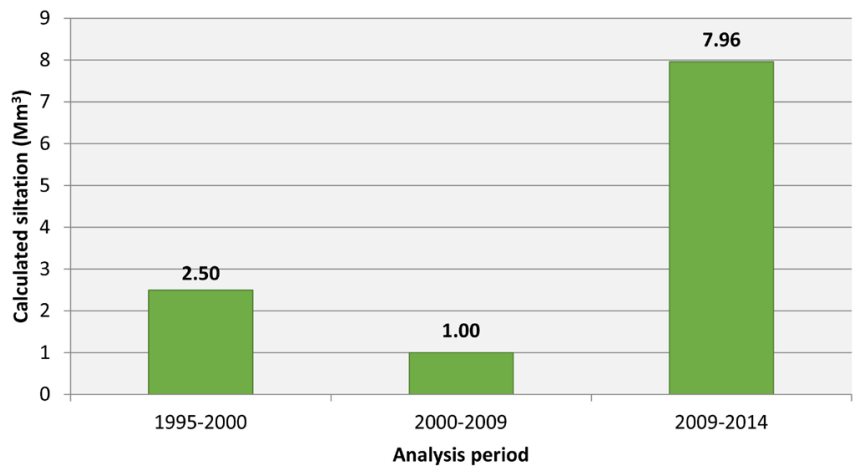

Figure 2. Siltation of the Hachef Dam for the 3 bathymetric analysis periods.

Referring to "Brune curve" (trapping rate of 97\%) and based on a silt density of 1.3, we obtain a Specific Degradation (SD) of the order of $3674 \mathrm{t} \cdot \mathrm{km}^{-2} \cdot \mathrm{yr}^{-1}$ characterizing the watershed upstream of the Hachef dam.

\subsection{Precipitation Factor Analysis}

At the study area level, there is a high spatial and temporal variability in precipitation (Figure 3 and Figure 4):

- Over time: variations are daily, seasonal (rain increases in winter and decreases until it stops in summer), annual and interannual. The fluctuations in the monthly evolution of precipitation recorded by the station 9 April shows a compatibility with the usual seasonal variations (winter, summer). The annual precipitation recorded by the station, for example, ranges from a minimum of $547.5 \mathrm{~mm}$ to a maximum of $2198.9 \mathrm{~mm}$, observed in 1996, with a mean, calculated between 1995 and 2014, of $993.8 \mathrm{~mm}$ and a standard deviation of $421.2 \mathrm{~mm}$. The magnitude of this standard deviation confirms the high interannual variability of precipitation.

- Spatially: During a rainy event, the intensity of the rain is rarely uniform over the entire study area. Rainfall varies between 400 and more than $1000 \mathrm{~mm}$ on the plains and hills in the West (Hachef, Tahadart, Ayacha, Tangier peninsula), the Loukkos plain in the South and the basins of Smir, Martil and Laou in the North. In the plains, annual rainfall is frequently less than $400 \mathrm{~mm}$. The 
influence of altitude is also felt in the number of rainy days per year. Rainfall also decreases from north to south (80 days in Tangier versus 60 days in Arbaoua).

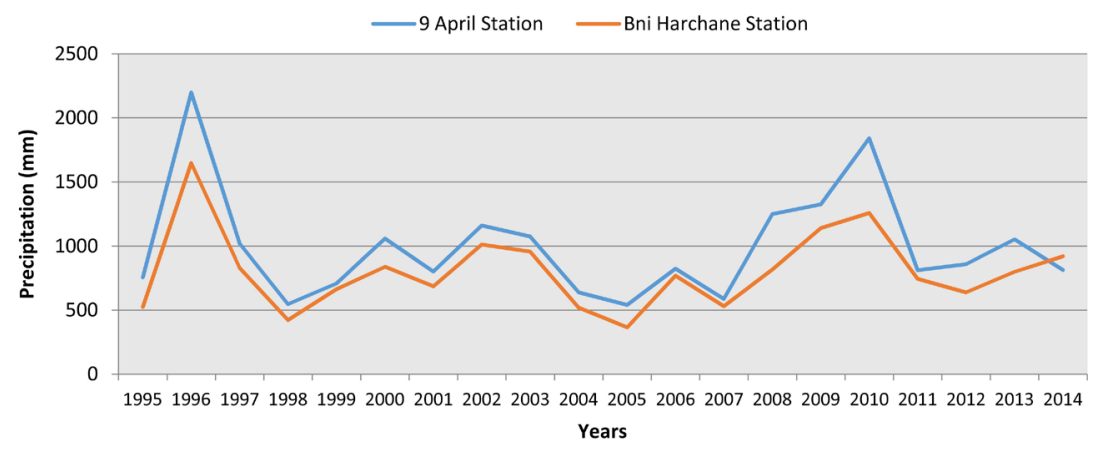

Figure 3. Annual precipitation trends for the two studied stations (1995-2014).

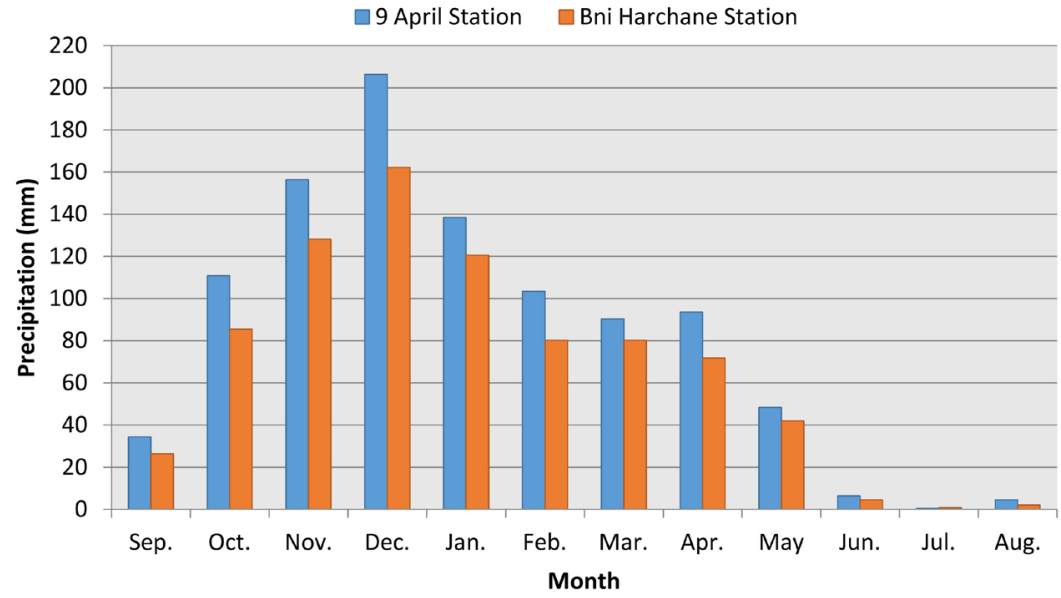

Figure 4. Evolution of monthly precipitation for the two studied stations (1995-2014).

The following Figure (Figure 5) illustrates the evolution of the annual rain erosivity for the two studied stations, calculated by the formula of Renard and Freimund:

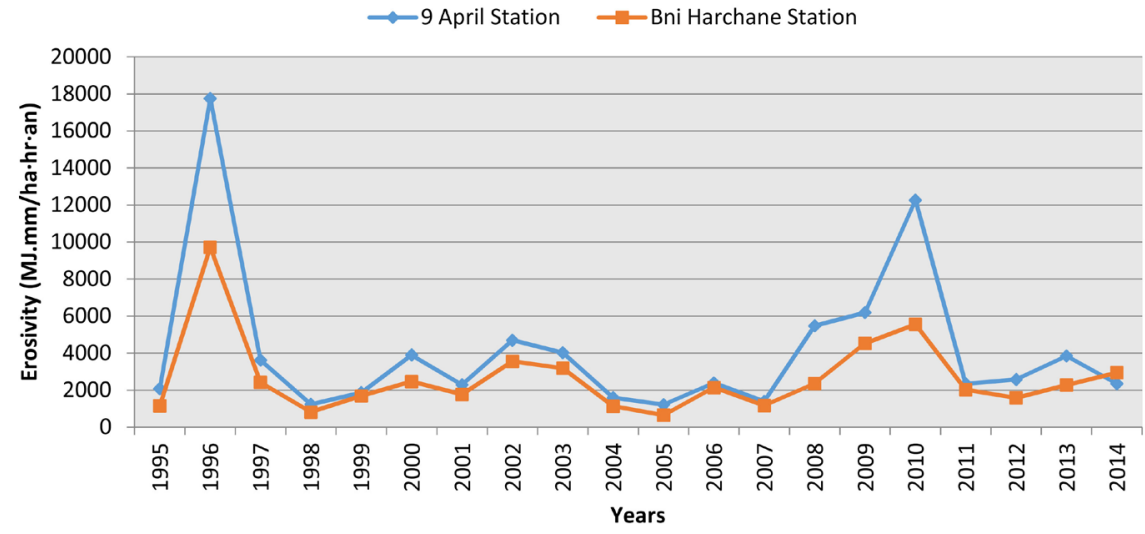

Figure 5. Changes in annual rainfall erosivity (1995-2014). 
The averages of the annual rainfall erosivity of the two stations studied are respectively of the order of 4062, 2765 and $3776 \mathrm{MJ} \cdot \mathrm{mm} / \mathrm{ha} \cdot \mathrm{hr} \cdot \mathrm{yr}$ for the three periods of analysis of the siltation rate.

The SD value thus established is higher than those of the two dams located near the Hachef dam (Ibn Batouta dam: $2995 \mathrm{t} \cdot \mathrm{km}^{-2} \cdot \mathrm{yr}^{-1}$ and Oued El Makhazen: $\left.2815 \mathrm{t} \cdot \mathrm{km}^{-2} \cdot \mathrm{yr}^{-1}\right)$.

It is also clearly higher than the DS values obtained by applying the two equations recommended within the framework of the study of the silting up of dams in Morocco. These equations, based on the watershed surface area alone or the combination of the watershed surface area and the average interannual run-off water level, respectively underestimated by 37 percent and 30 percent at the current degradation derived from bathymetry [16].

\subsection{Analysis of Land Cover Factor}

The study of vegetation dynamics based on the analysis of interannual variations in NDVI helps to draw up land cover maps for the four years corresponding to the dates of the bathymetric surveys (Figures 6-9).

An analysis of the watershed scale vegetation cover dynamics upstream of the Hachef Dam over the period 1995-2014 shows a decrease in "moderately dense" vegetation (7115 to $5406 \mathrm{ha}$ ) and an increase in sparse vegetation (3533 to 4919 ha). Changes in vegetation cover are illustrated in Figure 10 and Figure 11.

Comparison of the siltation rate of the Hachef Dam, calculated by analysing the four available bathymetric surveys, reveals a potential contribution of the spatial and temporal variability of the two dynamic factors of water erosion to the explanation of this siltation trend.

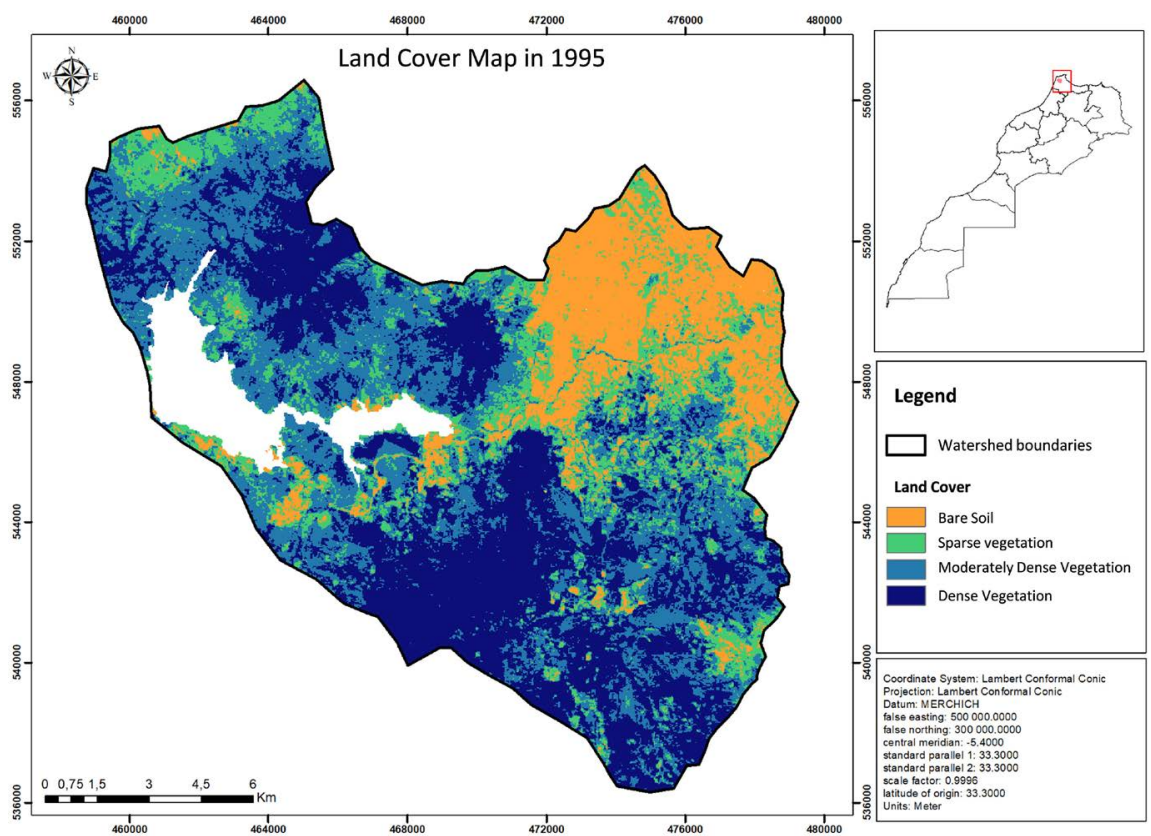

Figure 6. Land cover map in 1995. 


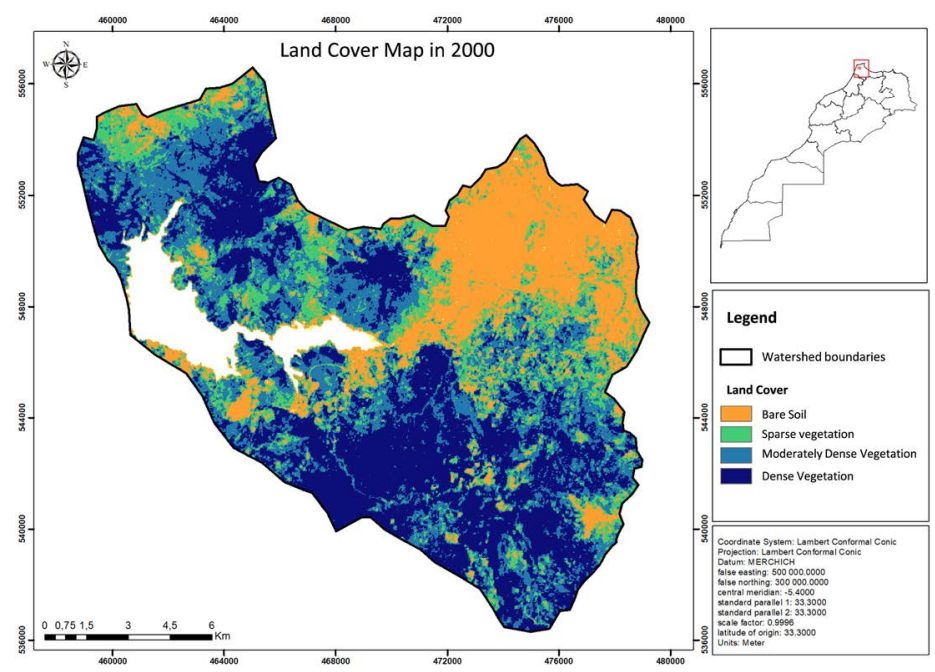

Figure 7. Land cover map in 2000.

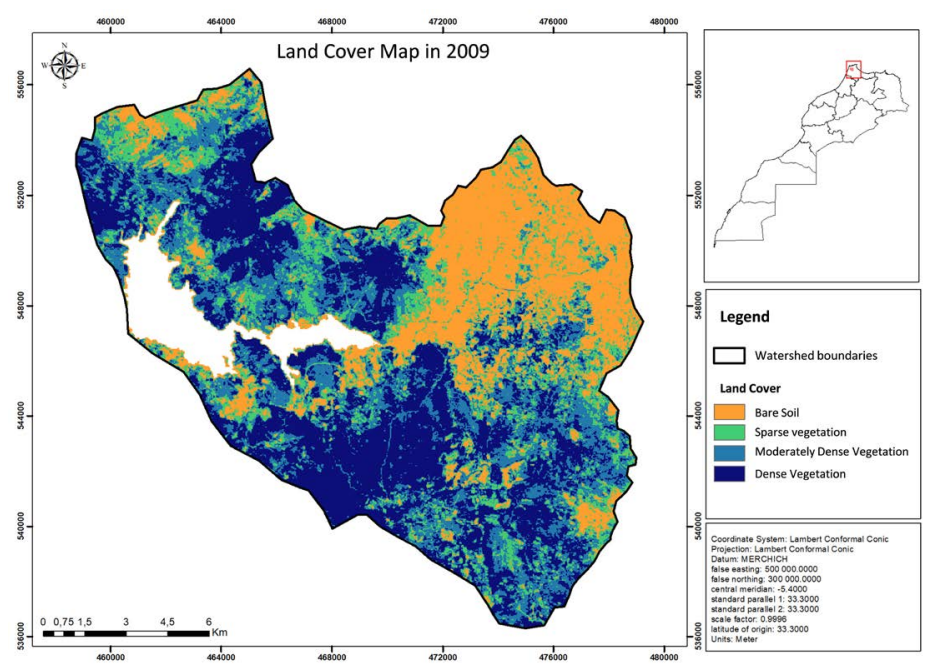

Figure 8. Land cover map in 2009.

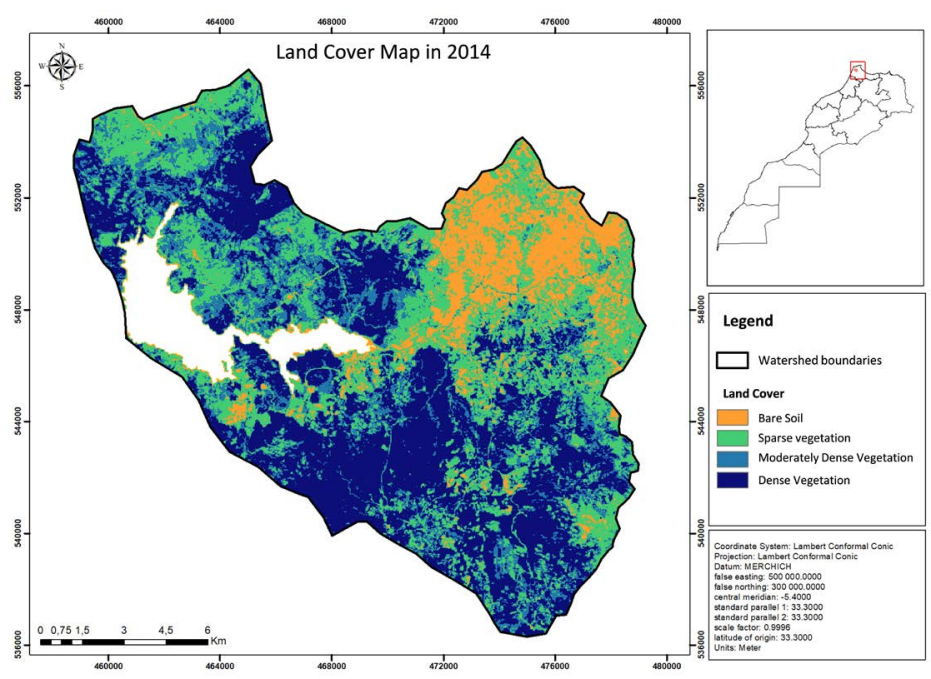

Figure 9. Land cover map in 2014. 


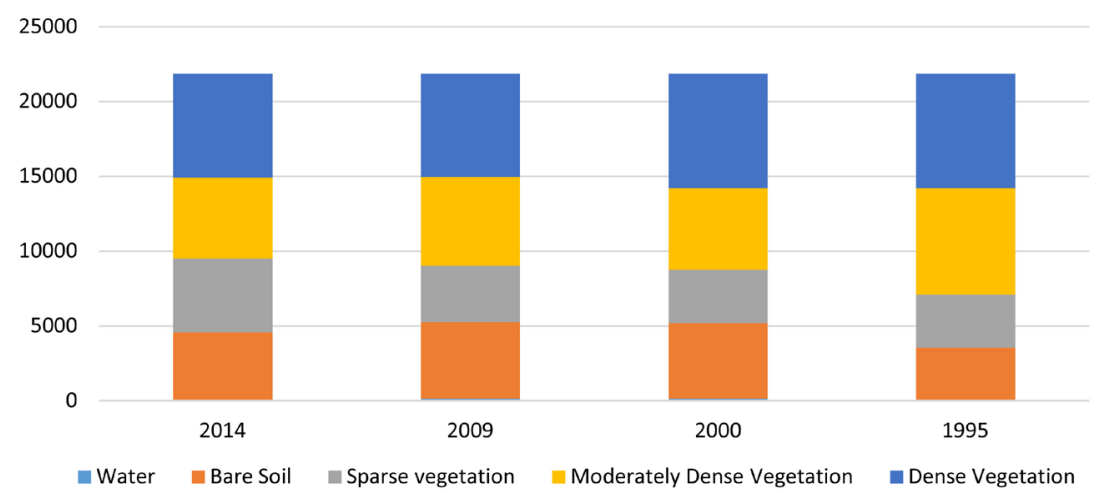

Figure 10. Changes in area of land use types.

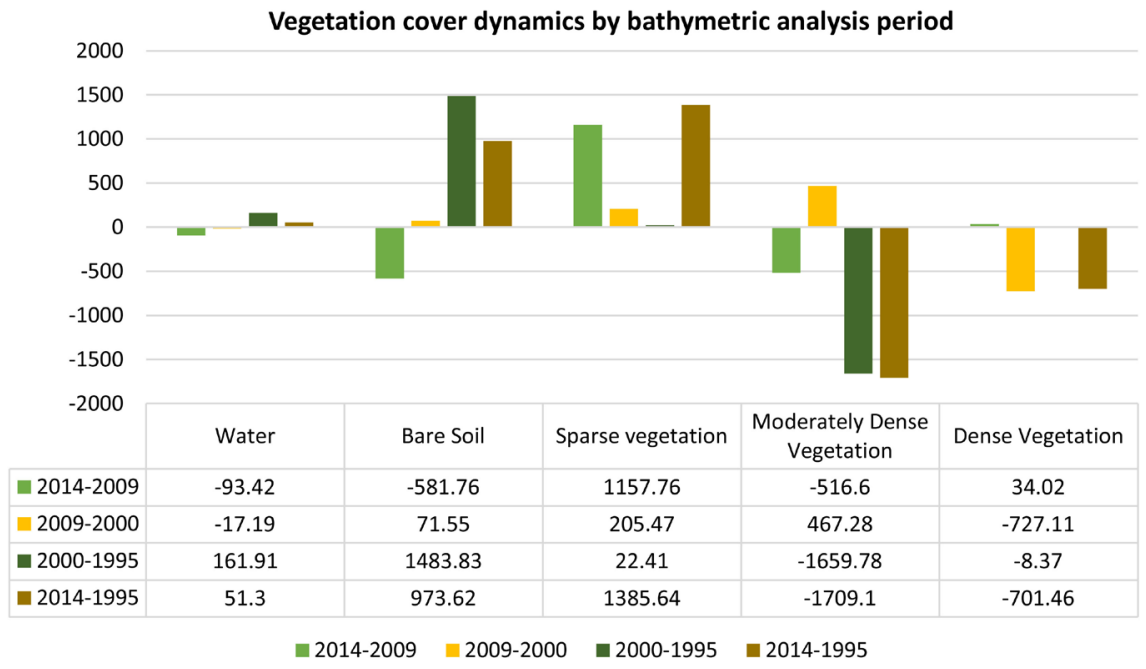

Figure 11. Vegetation cover dynamics by bathymetric analysis period.

- For the period 1995-2000, the dam lost an estimated $2.5 \mathrm{Mm}^{3}$ of water volume due to siltation of the reservoir, i.e. an average siltation rate of 0.5 $\mathrm{Mm}^{3} /$ year. During this period, the catchment area of the Hachef dam was marked by a fairly high level of rain erosion (annual average of around 4062 $\mathrm{MJ} . \mathrm{mm} / \mathrm{ha} \cdot \mathrm{hr} \cdot \mathrm{year}$ ) and a vegetation cover characterized by a clear regression of the medium dense vegetation ( $-1660 \mathrm{ha})$ and an increase in the occupation of bare ground (+1484 ha).

- During the period 2000-2009, the sedimentation of the dam reservoir recorded a siltation of $1 \mathrm{Mm}^{3}$, i.e. an annual sedimentation rate of around 0.11 $\mathrm{Mm}^{3} /$ year. During this period, the erosive nature of the rains was marked by a moderate value (annual average of around $2765 \mathrm{MJ} \cdot \mathrm{mm} / \mathrm{ha} \cdot \mathrm{hr} \cdot \mathrm{year}$ ) and less significant vegetative dynamics.

- During the period 2009-2014, the silting of the dam was estimated at 7.96 $\mathrm{Mm}^{3}$, i.e. an average annual silting rate of about $1.6 \mathrm{Mm}^{3} /$ year. The rains recorded during this period were characterized by a high level of erosivity (annual average of about $3776 \mathrm{MJ} \cdot \mathrm{mm} / \mathrm{ha} \cdot \mathrm{hr} \cdot \mathrm{yr}$ ). Vegetation cover was marked by a net increase in sparse vegetation $(+1158 \mathrm{ha})$. 


\section{Conclusions}

Commissioned in 1995 and considered as an essential hydraulic structure in the Tangier basin for the supply of drinking water to the cities of Tangier and Asilah, the Hachef dam is silting up at a rate of more than $36 \mathrm{t} / \mathrm{ha} / \mathrm{year}$.

The comparison of this Specific Degradation (SD) value with that estimated by bathymetry for regional dams, particularly for the Ibn Battouta dam (2995 $\mathrm{t} \cdot \mathrm{km}^{-2} \cdot \mathrm{yr}^{-1}$ ) shows that the Hachef catchment area is subject to strong erosion.

The results highlighted by this paper show the close link that can explain the rate of silting of the dam by the spatio-temporal dimension characterizing the two key factors of the phenomenon of hydric erosion (Aggressiveness of rainfall and Dynamics of the vegetation cover), and this, particularly in a territory such as that of Tangiers marked by notable global changes, and for which the surface water mobilization works are under construction (Kharroub Dam) or planned for the medium term (Ayacha Dam).

The results of this work indicate that dam management will increasingly need to be reconsidered in the context of global changes. Projected increases in the frequency and intensity of extreme climatic events associated with significant changes in land use and land cover may amplify the phenomenon of water erosion leading to siltation of dam reservoirs downstream, loss of the water volume and, hence, hindering the sustainability of hydraulic structures.

\section{Acknowledgements}

The authors would like to thank the Directorate of Water Research and Planning, the Loukkos River Basin Agency, the Regional Directorate of Agriculture of Tangier-Tetouan-Al Hoceima, the Regional Directorate of Water and Forestry and the Fight against Desertification of Rif-Tetouan and the JEAI-Vecteur Maroc Project.

\section{Conflicts of Interest}

The authors declare no conflicts of interest regarding the publication of this paper.

\section{References}

[1] Khattabi, A. and Croitoru, L. (2017) Chapitre 3: Eau. Le Coût de la Dégradation de l'Environnement au Maroc. World Bank Group Report, 147 p.

[2] Direction de la Recherche et de la Planification de l'Eau-DRPE (2014) Les sources de pollution de l'eau au Maroc. $24 \mathrm{p}$.

[3] Vezena, K. and Bonn, F. (2006) Modélisation et analyse de la dynamique spatio-temporelle des relations société-érosion et pollution diffuse en milieu agricole-étude de cas en Vietnam et au Québec. Interaction Nature-Société, analyse et modèles. UMR6554 LETG, La Baule, 6 p.

[4] Boudhar, A., Duchemin, B., Hanich, L., Chaponnière, A., Maisongrande, P., Boulet, G., Stitou, J. and Chehbouni, A. (2007) Analyse de la dynamique des surfaces enneigées du Haut Atlas Marocain à partir des données Spot-Vegetation. 
Sécheresse, 18, 278-288.

[5] Pandey, A., Mathur, A., Mishra, S.K. and Mal, B.C. (2009) Soil Erosion Modeling of a Himalayan Watershed Using RS and GIS. Environmental Earth Sciences, 59, 399-410. https://doi.org/10.1007/s12665-009-0038-0

[6] Fatiha, C., Chikhaoui, M., Naimi, M., Raclot, D., Pepin, Y. and Lafia, K. (2016) Impact du changement climatique sur l'évolution de l'érosivité des pluies dans le rif occidental (Nord Du Maroc). European Scientifique Journal, 12, 79. https://doi.org/10.19044/esj.2016.v12n32p79

[7] Agence du Bassin Hydraulique du Loukkos (ABHL) (2007) Etude d'actualisation du Plan Directeur d'aménagement intégré des ressources en eau (PDAIRE) des bassins Loukkos, Tangérois et Côtiers-méditerranéens. Volet: Ressources en eau superficielles, 192.

[8] Marzouki, T. (1992) Diagnostic de l'envasement des grands barrages au Maroc. $R e-$ vue Marocaine du Génie Civil, 38.

[9] Tayaa M. (1997) Bassin versant de Nakhla: Caractéristiques hydrologiques et estimation du taux d'érosion. Ministère de l'Environnement-USDA. WRS-Project, $60 \mathrm{p}$.

[10] Brune, G.M. (1953) Trap Efficiency of Reservoirs. Transactions of the American Geophysical Union, 34, 407-448. https://doi.org/10.1029/TR034i003p00407

[11] Chikhaoui, M., Bonn, F., Bokoye, A.I. and Merzouk, A. (2005) A Spectral Index for Land Degradation Mapping Using ASTER Data: Application to a Semi-Arid Mediterranean Catchment. International Journal of Applied Earth Observation and Geoinformation, 7, 140-153. https://doi.org/10.1016/j.jag.2005.01.002

[12] Nyssen, J., Vandenreyken, H., Poesen, J., Moeyersons, J., Deckers, J., Haile, M., Salles, C. and Govers, G. (2005) Rainfall Erosivity and Variability in the Northern Ethiopian Highlands. https://doi.org/10.1016/j.jhydrol.2004.12.016

[13] Vrieling, A., de Jong, S.M., Sterk, G. and Rodrigues, S.C. (2008) Timing of Erosion and Satellite Data: A Multi-Resolution Approach to Soil Erosion Risk Mapping. International Journal of Applied Earth Observations and Geo-Information, 10, 267-281. https://doi.org/10.1016/j.jag.2007.10.009

[14] Tadesse, L., Suryabhagavan, K.V., Sridhar, G. and Gizachew, L. (2017) Landuse and Landcover Changes and Soil Erosion in Yezat Watershed, North Western Ethiopia. International Soil and Water Conservation Research. https://doi.org/10.1016/j.iswcr.2017.05.004

[15] Rouse, J.W., Haas, R.H., Schell, J.A. and Deering, D.W. (1973) Monitoring vegetation systems in the Great Plains with ERTS. In: 3 rd ERTS Symposium, NASA SP-351 I, 309-317.

[16] El Boukhari, A., Naimi, M., Chikhaoui, M. and Raclot, D. (2019) Caractérisation de la dégradation spécifique pour la région septentrionale du Maroc. Revue Marocaine des Sciences Agronomiques et Vétérinaires, 7, No. 2. 